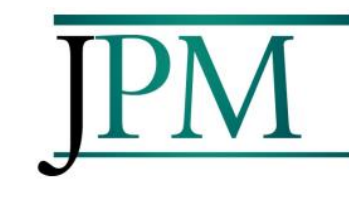

\title{
KEMAMPUAN REPRESENTASI MATEMATIS BERDASARKAN SELF- CONCEPT SISWA DENGAN PEMBELAJARAN LEARNING CYCLE 7E PADA MATERI GARIS KELAS VII SMP NEGERI 1 DAU MALANG
}

\author{
Nur Hasanah \\ Program Studi Pendidikan Matematika FKIP UNISMA \\ Email: ${ }^{I}$.hasanahmz@yahoo.com
}

\begin{abstract}
Abstrak
Penelitian ini bertujuan untuk mengetahui kemampuan representasi matematis siswa yang memiliki selfconcept positif dan negatif yang diajar dengan model learning cycle $7 E$. Metode penelitian yang digunakan adalah penelitian kombinasi. Penelitian dilakukan malalui dua tahap penelitian, tahap pertama dengan metode kuantitatif dan tahap kedua dengan metode kualitatif. Teknik dan alat pengumpulan data kuantitatif menggunakan teknik tes dan kuesioner dengan instrumen tes uraian kemampuan representasi matematis dan angket self-concept. Teknik pengumpulan data kualitatif menggunakan observasi dan wawancara. Hasil uji $t$ dua pihak pada data kemampuan representasi matematis siswa dengan self-concept positif dan negatif berturut diperoleh nilai Sig. $(2$-tailed $)=0,009$ dan Sig. $(2$-tailed $)=0,06$ lebih besar dari 0,05 sehingga $\mathrm{H}_{0}$ ditolak yang artinya terdapat perbedaan kemampuan reprsentasi matematis antara kelas eksperimen dan kelas kontrol untuk siswa dengan self-concept positif dan negatif. Hasil analisis data kualitatif diperoleh bahwa kemampuan representasi matematis siswa dengan self-concept positif dan negatif kelas eksperimen termasuk dalam kategori cukup baik. Kemampuan representasi matematis siswa dengan self-concept positif kelas kontrol termasuk dalam kategori baik. Kemampuan representasi matematis siswa dengan self-concept negatif kelas kontrol termasuk dalam kategori kurang baik. Hasil analisis data kuantitatif dan kualitatif menunjukkan bahwa terdapat perbedaaan kemampuan representasi matematis yang signifikan antara kelas eksperimen dan kelas kontrol baik siswa yang memiliki selfconcept positif maupun negatif.
\end{abstract}

Kata-kata kunci: kemampuan representasi matematis, model pembelajaran learning cycle $7 E$, self-concept, garis.

\section{PENDAHULUAN}

Melihat arti pentingnya matematika dalam pengembangan ilmu pengetahuan dan teknologi, sudah selayaknya matematika dipelajari sejak sekolah dasar hingga perguruan tinggi sebagaimana tujuan matematika adalah untuk melatih siswa berpikir kritis, kreatif, dan bertanggung jawab. Peraturan Menteri Pendidikan Nasional Nomor 22 Tahun 2006 menegaskan tujuan pembelajaran matematika, yaitu (1) mampu menguasai konsep matematika, mendeskripsikan keterikatan konsep, dan menerapkan konsep dengan fleksibel, teliti, tepat guna dan cocok dalam memecahkan masalah, (2) mampu memanfaatkan penalaran untuk melakukan manipulasi matematika dalam membuat abstraksi, membuktikan, atau menjelaskan gagasan dan pernyataan matematika, (3) mampu menyelesaikan masalah mencakup kemampuan memahami masalah, membuat model, menyelesaikan model, dan mengartikan solusi yang diperoleh, (4) mampu menyampaikan gagasan dengan representasi lain atau media lain untuk memperjelas suatu masalah, dan (5) mengetahui dan menghargai manfaat matematika dalam kehidupan sehari-hari, yaitu dengan menunjukkan rasa ingin tahu, perhatian, dan minat dalam belajar matematika, serta sikap tekun dan percaya diri dalam menyelesaikan masalah. Untuk mencapai tujuan tersebut, siswa harus memiliki kemampuan matematis yang matang, sehingga dapat menguasai dan mengintegrasi matematika ke dalam bidang ilmu pengetahuan lainnya.

NCTM (2000:9) menyebutkan lima standar kemampuan matematis, yaitu pemecahan masalah (problem solving), penalaran dan pembuktian (reasoning and proof), komunikasi (communication), koneksi (connection), dan representasi (representation). Kelima standar tersebut 
merupakan aspek fundamental dalam matematika untuk mengembangkan kemampuan berpikir matematis siswa. Salah satu aspek fundamental tersebut adalah representasi yang memiliki fungsi yang sejajar dengan komponen lainnya.Karakteristik matematika yang abstrak dan kaya akan simbol, dibutuhkan suatu kemampuan yang dapat menginterpretasi konsep matematika kedalam bahasa yang lebih mudah dipahami. Kemampuan yang dimaksud adalah kemampuan representasi matematis. Goldin (2002:207) menyatakan bahwa representasi merupakan unsur penting dalam teori belajar mengajar matematika. Alasan yang mendasari pentingnya representasi dalam matematika, yaitu (1) matematika menggunakan bahasa simbol, (2) matematika mempunyai peran penting dalam mengkonseptualisasi dunia nyata, dan (3) penggunaan matematika yang luas dimana struktur menjadi saling terkoneksi. Dengan demikian, kemampuan representasi merupakan kemampuan yang harus dimiliki oleh setiap individu dalam mempelajari matematika.

Triono (2017:67) menyebutkan dalam penelitiannya bahwa kesalahan-kesalahan siswa dalam merepresentasikan disebabkan oleh rendahnya kemampuan siswa dalam merepresentasikan permasalahan yang diberikan. Siswa menunjukkan ketidakpahaman dalam menggunakan simbolsimbol matematika. Hal ini terjadi karena beberapa faktor, salah satunya adalah cara guru mengajar dan cara siswa belajar. Kebiasaan pembelajaran secara konvensional belum mampu meningkatan kemampuan matematis siswa secara optimal, karena pembelajaran konvensional cenderung pada penyampaian konsep atau teori saja.

Berdasarkan hasil wawancara dengan salah satu guru matematika di SMP Negeri 1 Dau Malang menyampaikan bahwa proses pembelajaran mayoritas masih menggunakan model pembelajaran konvensional meskipun kurikulum yang digunakan adalah kurikulum 2013 dimana pada kurikulum ini pembelajaran berpusat pada siswa. Alasan yang disampaikan adalah ketuntasan materi dan hasil belajar siswa lebih diutamakan. Namun, hasil belajar matematika siswa kelas VII sebagian besar masih dibawah KKM yang telah ditentukan yaitu 80, misalnya pada siswa kelas VII F. Siswa kelas VII F yang memperoleh nilai UTS diatas KKM hanya sebanyak 7 siswa dari 29 siswa. Hal ini, diduga karena penggunaan model pembelajaran yang masih konvensional yang berakibat pada pengalaman siswa dalam belajar menjadi berkurang dan siswa hanya menjadi peniru dari apa yang dikerjakan oleh guru. Hutagaol (dalam Fitri, Munzir, \& Duskri, 2017:60) menyatakan bahwa kurang berkembangnya kemampuan representasi matematis siswa disebabkan oleh kurangnya kesempatan siswa untuk menghadirkan representasinya sendiri tetapi harus mengikuti apa yang dicontohkan oleh gurunya. Dengan demikian penggunaan model konvensional menghambat perkembangan kemampuan representasi matematis siswa.

Terkait permasalahan kesenjangan penerapan kurikulum 2013 yang berakibat pada terhambatnya perkembangan kemampuan representasi matematis siswa, Suryowati (2015:50) merekomendasikan kepada guru untuk dapat memilih dan menggunakan pendekatan pembelajaran yang tepat, sehingga proses pembelajaran berlangsung optimal dan mampu mengembangkan kemampuan representasi matematis. Salah satu kompetensi yang harus dimiliki oleh guru adalah kemampuan dalam memilih model, pendekatan, dan motode pembelajaran yang tepat, sehingga dapat memberikan pengaruh yang optimal dalam mengembangkan potensi yang dimilki oleh siswa. Salah satu model pembelajaran yang dapat digunakan oleh guru adalah model pembelajaran learning cycle $7 E$.

Ruseffendi (dalam Laelasari, Subroto, \& Duskri, 2014:84) berpendapat bahwa untuk menarik minat siswa terhadap matematika, siswa harus mengetahui kegunaan dan keindahannya. Model Learning cycle $7 E$ diduga dapat memberikan kesempatan kepada siswa untuk memperoleh pengalaman secara langsung dengan lingkungannya, sehingga siswa dapat mengetahui kegunaan konsep yang dipelajari. Dugaan tersebut didasarkan pada fase-fase belajar dalam learning cycle secara umum. Carin (dalam Jatmiko, 2017:85) menyampaikan fase-fase belajar dalam learning cycle, yaitu (1) siswa dapat memperoleh pengalaman langsung dengan lingkungan, (2) siswa dapat membangun konsep pengetahuannya sendiri, dan (3) siswa ditekankan untuk dapat menerapkan 
konsep yang dipahami pada situasi baru. Dengan demikian, model pembelajaran learning cycle $7 E$ dapat meningkatkan kemampuan berpikir siswa.

Berkembangnya kemampuan berpikir siswa dipengaruhi oleh faktor eksternal dan internal siswa. Faktor eksternal berasal dari luar diri siswa yaitu dari lingkungan sekitar siswa, sedangkan faktor internal berasal dari dalam diri siswa sendiri. Salah satu faktor internal yang dapat mempengaruhi kemampuan berpikir siswa adalah self-concept siswa. Self-concept adalah pandangan individu mengenai ide, pikiran, kepercayaan dan pendirian tentang dirinya sendiri yang juga dipengaruhi oleh pandangan seseorang terhadap dirinya. Menurut Burns (dalam Rahman, 2012:20) pendapat individu tentang dirinya yang dipengaruhi oleh cara individu menilai pendapat orang lain terhadap dirinya memberikan dampak dan kondisi yang berbeda, akibatnya setiap individu memiliki kemampuan yang berbeda-beda. Kemampuan yang berbeda-beda merupakan akibat dari hasil refleksi individu terhadap dirinya sendiri yang disebut sebagai "self-concept".

Tujuan dalam penelitian ini adalah:

1) untuk mengetahui adanya perbedaan kemampuan representasi matematis antara siswa yang diajar menggunakan model learning cycle $7 E$ dan model konvensional untuk siswa yang memiliki self-cocept positif pada materi garis kelas VII SMPN 1 Dau Malang.

2) untuk mengetahui adanya perbedaan kemampuan representasi matematis antara siswa yang diajar menggunakan model learning cycle $7 E$ dan model konvensional untuk siswa yang memiliki self-cocept negatif pada materi garis kelas VII SMPN 1 Dau Malang.

3) untuk mendeskripsikan kemampuan representasi matematis siswa yang diajar menggunakan model learning cycle $7 E$ dan model konvensional berdasarkan jenis self-concept yang dimiliki pada materi garis kelas VII SMPN 1 Dau Malang.

\section{METODE}

jenis penelitian yang digunakan dalam penelitian ini adalah penelitian kombinasi. Desain yang dugunakan adalah sekuensial ekplanatori, yaitu penelitian kombinasi yang menggabungkan metode kuantitatif dan kualitatif secara berurutan. Metode kuantitatif berguna untuk mengumpulkan data yang terukur, sedangkan metode kualitatif menyempurnakan, memperluas, atau menjelaskan gambaran umum kuantitatif (Creswell, 2015:1107).

Pada tahap pertama penelitian ini, peneliti menggunakan metode penelitian kuantitatif jenis eksperimen semu (quasi experiment), yaitu metode penelitian yang mempunyai kelompok kontrol tetapi tidak dapat berfungsi sepenuhnya untuk mengontrol variabel-variabel luar yang mempengaruhi pelaksanaan eksperimen. Eksperimen semu melibatkan penempatan (tetapi bukan penempatan random) partisipan ke kelompok (Creswell, 2015:607). Alasan peneliti menggunakan eksperimen semu karena penelitian dilaksanakan di lembaga pendidikan, dimana kelas sudah terbentuk dan tidak dapat diubah. Apabila peneliti menempatkan siswa secara random pada kedua kelompok akan berakibat pada tergangganggunya proses pembelajaran. Desain eksperimen semu yang digunakan adalah Nonequivalent Control Group. Menurut Sugiyono (2016:118) desain nonequivalent control group memiliki kelompok eksperimen dan kelompok kontrol seperti pada desain pretest-posstest control group, tetapi pada desain nonequivalent control group kelompok tersebut tidak dipilih secara random. Populasi adalah semua siswa kelas VII SMP Negeri 1 Dau Malang dengan jumlah total 193 siswa. Pengacakan yang biasa digunakan pada desain nonequivalent control group adalah cluster random sampling. Hal ini dapat dilakukan apabila populasi yang diambil memiliki karakteristik yang homogen/relatif homogen. Jika populasi tidak homogen, maka teknik sampling yang memungkinkan adalah Purposive Sampling (Lestari \& Yudhanegara, 2017:138). Pengambilan sampel dalam penelitian ini menggunakan teknik Purposive Sampling karena peneliti memiliki pertimbangan tertentu terhadap sampel-sampel yang akan diteliti. Teknik Purposive Sampling adalah teknik pengambilan sampel berdasarkan pertimbangan tertentu (Sugiyono, 2016:126). Pertimbangan pengambilan sampel dalam penelitian ini adalah: 
1) Kelas telah terbagi sejak awal sehingga tidak memungkinkan untuk mengubah peraturan kelas yang telah ada.

2) Populasi memiliki karakteristik yang tidak homogen.

3) Kelas dipilih berdasarkan rekomendasi guru matematika yang telah memenuhi kriteria sebagai berikut:

(a) Kelas tersebut telah mencapai materi garis.

(b) Kelas tersebut memiliki kemampuan yang relatif sama.

Kemampuan yang sama dari kedua kelas ditunjukkan melalui hasil nilai UTS siswa dibandingkan dengan nilai KKM sekolah, yaitu 80. Dalam penelitian ini sampel yang diambil terbatas 2 kelas yang terdapat di SMPN 1 Dau Malang, yaitu kelas VII D sebagai kelas Eksperimen dan kelas VII E sebagai kelas kontrol. Nilai UTS yang diperoleh masing-masing kelas menunjukkan bahwa pada kelas VII D siswa yang memperoleh nilai diatas KKM sebanyak 12 siswa, sedangkan pada kelas VII E siswa yang memperoleh nilai diatas KKM sebanyak 14 siswa. Dengan demikian, kedua kelas memiliki kemampuan yang sama atau relatif sama. Teknik pengumpulan data tahap pertama dilakukan dengan teknik tes dan kuesioner. Teknik tes digunakan untuk mengukur kemampuan representasi matematis siswa. Teknik kuesioner digunakan untuk mengambil data selfconcept siswa.

Intrumen penelitian pada tahap pertama ini berupa soal tes kemampuan representasi matematis dan lembar angket self-concept. Instrumen soal tes berupa lembar soal pretest dan posttest yang dikembangkan berdasarkan indikator kemampuan representasi matematis dan disajikan dalam bentuk soal uraian (essay). Tes awal (pretest) digunakan untuk mengetahui kemampuan representasi matematis awal siswa kelas eksperimen dan kelas kontrol, sedangkan tes akhir (posttest) digunakan untuk mengetahui sejauh mana kemampuan representasi matematis pada kelas eksperimen dan kelas kontrol setelah penerapan model pembelajaran pada masing-masing kelompok. Perhitungan analisis data kuantitatif menggunakan sefware SPSS 23. Analisis data kuatitatif dalam penelitian ini meliputi uji prasyarat dan uji hipotesis dengan taraf signifikansi 0,05 . Uji prasyarat yang digunakan adalah uji normalitas. uji kemampuan awal siswa dianalisis melalui uji $t$ dua pihak dari data pretest. Uji hipotesis yang digunakan adalah uji $t$ dua pihak. Uji $t$ dua pihak digunakan untuk mengetahui perbedaan kemampuan representasi matematis kelas eksperimen dan kelas kontrol berdasarkan jenis self-concept yang dimiliki siswa.

Pada tahap kedua, peneliti menggunakan metode penelitian kualitatif. Pada bagian ini peneliti merupakan instrumen utama, sehingga kehadirannya sangat diperhitungkan. Instrumen utama berarti peneliti berperan sebagai perencana, pelaksana, pengendali, pengumpul dan penganalisis data, penarik kesimpulan dan pembuat laporan hasil penelitian. Jenis penelitian yang digunakan adalah kualitatif deskriptif. Subjek penelitian kualitatif yang digunakan terdiri dari 2 siswa dengan sel-concept positif dan 2 siswa dengan self-concept negatif yang diambil dari kelas eksperimen dan kelas kontrol. Subjek penelitian dipilih berdasarkan hasil angket self-concept dan hasil posttest kemampuan representasi matematis siswa.

Teknik pengumpulan data kualitatif yang digunakan adalah non-tes. Pengumpulan data melalui teknik non-tes dapat ditempuh dengan beberapa cara, yaitu kuesioner, wawancara, dan observasi. Adapun teknik non-tes yang digunakan dalam penelitian ini adalah observasi dan wawancara. Observasi dilakukan sebagai data pendukung penelitian untuk memperoleh informasi tentang bagaimana guru melaksanakan pembelajaran. Hal ini dilakukan untuk memastikan proses pembelajaran telah sesuai dengan rancangan pembelajaran yang telah disusun, sehingga dapat membuktikan bahwa hasil yang diperoleh merupakan akibat dari perlakuan yang diberikan. Wawancara dilakukan untuk mengetahui kemampuan representasi matematis siswa yang memiliki self-concept positif dan negatif lebih mendalam.

Instrumen pendukung dalam penelitian ini terdiri dari lembat observasi dan pedoman wawancara. Lembar observasi yang digunakan terdiri dari lembar observasi kegiatan guru dan kegiatan siswa dengan skala penilaian yang telah ditentukan. Penyusunan pedoman wawancara 
disesuaikan dengan indikator kemampuan representasi matematis. Uji keabsahan data menggunakan uji kredibilitas dengan teknik triangulasi. Teknik analisis data kualitatif menggunakan model Miles dan Huberman yang meliputi reduksi data, penarikan kesimpulan dan verifikasi.

\section{HASIL}

Dalam penelitian ini, hasil penelitian meliputi hasil analisis kuantitatif dan kualitatif. Data kuantitatid diperoleh melalui penelitian tahap pertama (kuantitatif) dan data kualitatif diperoleh melalui penelitian tahap kedua (kualitatif). Dari hasil analisis kedua metode penelitian, selanjutnya akan dibandingkan dan diambil kesimpulan. Adapun uraian tentang hasil penelitian sebagai berikut.

Sampel yang dipilih sebagai sampel penelitian tahap pertama (kuantitatif) adalah kelas VII D sebagai kelas kontrol dan kelas VII E sebagai kelas eksperimen. Sebelum dilakukan perlakuan pada masing-masing kelas, peneliti memberikan tes awal (pretest) untuk mengetahui kemampuan awal masing-masing kelompok sampel sebelum diberikan perlakuan. Selain memberikan tes awal, kelompok sampel mengisi angket self-concept untuk mengetahui jenis self-concept yang dimiliki masing-masing siswa. Data angket menjadi dasar pengelompokan siswa berdasarkan jenis selfconcept positif dan negatif dari masing-masing kelas. Data pretest dianalisis dengan uji kesamaan rata-rata menggunakan sofware SPSS 23 melalui independent sample $t$ test, untuk mengetahui kemampuan awal semua sampel. Apakah sampel penelitian berangkat dari kemampuan yang sama sebelum diberi perlakuan. Sebelum dilakukan analisis, prasyarat pengujian harus terpenuhi yaitu uji normalitas. hasil uji normalitas dari data sampel siperoleh bahwa semua data sampel berdistribusi normal. Adapun hasil uji $t$ dua pihak dapat dilihat pada Tabel 1.

Tabel 1: Hasil Uji $t$ Dua Pihak Nilai Pretest Kemampuan Representasi Matematis

\begin{tabular}{llllll}
\hline Kelas & $\begin{array}{l}\text { Self- } \\
\text { Concept }\end{array}$ & $\begin{array}{l}\text { Jumlah } \\
\text { Siswa (n) }\end{array}$ & Rata-rata \pm Standar Deviasi & df & Sig \\
\hline Eksperimen & Positif & 16 & $21,8750 \pm 10,91847$ & 0,652 \\
\cline { 1 - 4 } Kontrol & Negatif & 9 & $20,8333 \pm 10,20621$ & \\
\hline & Positif & 16 & $20,3125 \pm 8,31595$ & 0,687 \\
\hline
\end{tabular}

Keterangan: jika Sig (2-tailed) > 0,05 berarti tidak ada perbedaan yang bermakna dan jika Sig (2tailed) $\leq 0,05$ berarti ada perbedaan yang bermakna.

Berdasarkan hasil uji kesamaan rata-rata pretest kemampuan representasi matematis untuk siswa yang memiliki self-concept positif pada Tabel 1 diperoleh nilai Sig 2-tailed $=0,652>0,05$ sehingga $\mathrm{H}_{0}$ diterima. Hal ini berarti tidak terdapat perbedaan kemampuan awal yang signifikan antara kelas eksperimen (VII D) dan kelas kontrol (VII E) untuk siswa yang memiliki self-concept positif, dengan kata lain kemampuan awal kedua kelas untuk siswa yang memiliki self-concept positif adalah sama. Hasil uji kesamaan rata-rata pretest kemampuan representasi matematis untuk siswa yang memiliki self-concept negatif pada Tabel 4.5 diperoleh nilai Sig 2-tailed $=0,687>0,05$ sehingga $\mathrm{H}_{0}$ diterima. Hal ini berarti tidak terdapat perbedaan kemampuan awal yang signifikan antara kelas eksperimen (VII D) dan kelas kontrol (VII E) untuk siswa yang memiliki self-concept negatif, dengan kata lain kemampuan awal kedua kelas untuk siswa yang memiliki self-concept negatif adalah sama. Hasil analisis ini memberikan informasi bahwa kemampuan kedua kelas sebelum dilakukan perlakuan berangkat dari keadaaan yang sama.

Setelah dilakukan perlakuan pada masing-masing kelas, yaitu kelas VII D sebagai kelas kontrol yang diajar dengan mmodel konvensional dan kelas VII E sebagai kelas eksperimen yang diajar dengan model learning cycle $7 E$, maka kedua kelas akan diberikan tes akhir (posttest) kemampuan representasi matematis. Tes akhir dilakukan untuk mengetahui kemampuan representasi matematis siswa setelah diberikan perlakuan. Data hasil posttest dijadikan dasar untuk menjawab rumusan masalah. Teknik analisis data posttest dilakukan melalui uji kesamaan rata-rata dua pihak dengan menggunakan sofware SPSS 23. Sebelum dilakukan uji kesamaan rata-rata dua 
pihak, data sampel harus terbukti berdistribusi normal.hasil uji normalitas diperoleh bahwa data sampel penelitian berasal dari populasi yang berdistribusi normal. Adapun hasil uji kesamaan ratarata diperoleh seperti pada Tabel 2 .

Tabel 2: Uji $t$ Dua Pihak Nilai Posttest Kemampuan Representasi Matematis

\begin{tabular}{llllll}
\hline Kelas & $\begin{array}{l}\text { Self- } \\
\text { Concept }\end{array}$ & $\begin{array}{l}\text { Jumlah } \\
\text { Siswa } \\
(\mathbf{n})\end{array}$ & Rata-rata \pm Standar Deviasi & $\boldsymbol{d}$ f & sig \\
\hline Eksperimen & Positif & 16 & $79,4271 \pm 8,25922$ & \multirow{2}{*}{30} & 0,009 \\
\hline Nogatif & 9 & $75,0000 \pm 10,20553$ & 0,005 \\
\hline & Positif & 16 & $69,5315 \pm 11,45876$ & \multirow{2}{*}{16} & \\
\hline
\end{tabular}

Keterangan: jika Sig (2-tailed) > 0,05 berarti tidak ada perbedaan yang bermakna dan jika Sig (2tailed $\leq \leq 0,05$ berarti ada perbedaan yang bermakna.

Berdasarkan hasil uji kesamaan rata-rata posttest kemampuan representasi matematis untuk siswa yang memiliki self-concept positif pada Tabel 2 diperoleh nilai Sig 2-tailed $=0,009 \leq 0,05$ sehingga $\mathrm{H}_{0}$ diterima. Hal ini berarti terdapat perbedaan kemampuan awal yang signifikan antara kelas eksperimen (VII D) dan kelas kontrol (VII E) untuk siswa yang memiliki self-concept positif. Hasil uji kesamaan rata-rata pretest kemampuan representasi matematis untuk siswa yang memiliki self-concept negatif pada Tabel 2 diperoleh nilai Sig 2-tailed $=0,005 \leq 0,05$ sehingga $\mathrm{H}_{0}$ diterima. Hal ini berarti terdapat perbedaan kemampuan awal yang signifikan antara kelas eksperimen (VII D) dan kelas kontrol (VII E) untuk siswa yang memiliki self-concept negatif. Berdasarkan data diperoleh rata-rata kemampuan representasi matematis kelas eksperimen adalah 79,4271 lebih besar dari kemampuan representasi matematis kelas kontrol yiatu 69,5315 untuk siswa yang memiliki self-concept positif. Untuk siswa yang memiliki self-concept negatif, kemampuan representasi matematis kelas eksperimen adalah 75,0000 lebih besar dari kelas kontrol yaitu 55,5552. Dengan demikian, kemampuan representasi matematis siswa kelas eksperimen lebih baik dari pada kelas kontrol baik untuk siswa yang memiliki self-concept positif maupun negatif.

Data kualitatif yang diperoleh adalah data observasi kegiatan guru dan siswa serta data hasil wawancara kemampuan representasi matematis. Observasi dilakukan untuk mengetahui kegiatan guru dan siswa selama proses pembelajaran. Wawancara dilakukan untuk mendeskripsikan kemampuan representasi matematis siswa yang memiliki self-concept positif dan negatif. Hasil observasi kegiatan guru kelas eksperimen dan kelas kontrol dapat dilihat pada Tabel 3 dan Tabel 4, sedangkan hasil observasi kegiatan siswa dapat dilihat pada Tabel 5 dan Tabel 6.

Tabel 3: Data Observasi Kegiatan Guru Kelas Eksperimen

\begin{tabular}{lll}
\hline Pertemuan Ke- & Skor Pengamat I & Skor Pengamat II \\
\hline Pertemuan ke-1 & 88 & 90 \\
\hline Pertemuan ke-2 & 99 & 98 \\
\hline Pertemuan ke-3 & 100 & 100 \\
\hline Skor rata-rata & 95,67 & 96 \\
\hline Persentase kegiatan & $83,19 \%$ & $83,48 \%$ \\
\hline Taraf keberhasilan & Sangat Baik & Sangat Baik \\
\hline
\end{tabular}

Berdasarkan hasil observasi kegiatan guru, diketahui bahwa guru telah melakukan kegiatan pembelajaran dengan baik dengan taraf keberhasilan sebesar $80,06 \%$. Hal ini ditunjukkan dengan kesesuaian kegiatan guru dengan langkah-langkah model pembelajaran learning cycle $7 E$, yaitu (1) guru telah memberikan stimulus untuk merangsang keingintahuan siswa dengan memberikan contoh-contoh dalam kehidupan sehari-hari yang berhubungan dengan materi garis, (2) guru telah melibatkan siswa dalam diskusi tentang fenomena yang sering terjadi dalam kehidupan sehari-hari yang berhubungan dengan materi garis, (3) guru memberikan waktu kepada siswa untuk berdiskusi 
bersama kelompoknya tentang materi yang dipelajari, (4) guru telah memotivasi, memberi petunjuk seperlunya serta memberikan bimbingan kepada siswa dalam menyelesaikana masalah, dan (5) guru telah membimbing siswa untuk menerapkan konsep yang dipelajari pada situasi baru dan kehidupan nyata.

Tabel 4: Data Observasi Kegiatan Guru Kelas Kontrol

\begin{tabular}{lll}
\hline Pertemuan Ke- & Skor Pengamat I & Skor Pengamat II \\
\hline Pertemuan ke-1 & 86 & 86 \\
\hline Pertemuan ke-2 & 86 & 85 \\
\hline Pertemuan ke-3 & 86 & 88 \\
\hline Skor rata-rata & 86 & 86,33 \\
\hline Persentase kegiatan & $86 \%$ & $86,33 \%$ \\
\hline Taraf keberhasilan & Sangat Baik & Sangat Baik \\
\hline
\end{tabular}

Berdasarkan hasil observasi kegiatan guru, diketahui bahwa guru telah melakukan kegiatan pembelajaran dengan sangat baik dengan taraf keberhasilan sebesar $86,17 \%$. Kegiatan guru pada kelas kontrol lebih menekankan pada penjelasan konsep maupun prosedur penyelesaian masalah dari pada memberikan kesempatan kepada siswa untuk mengeksplor kemampuannya. Dengan demikian, kegiatan pembelajaran pada kelas kontrol berpusat pada guru. Sedangkan siswa menerima apa yang telah disampaikan oleh guru, sehingga kegiatan pembelajaran dikelas menjadi pasif.

Tabel 5: Data Observasi Kegiatan Siswa Kelas Eksperimen

\begin{tabular}{lll}
\hline Pertemuan Ke- & Skor Pengamat I & Skor Pengamat II \\
\hline Pertemuan ke-1 & 94 & 92 \\
\hline Pertemuan ke-2 & 107 & 106 \\
\hline Pertemuan ke-3 & 107 & 108 \\
\hline Skor rata-rata & 102,67 & 102,33 \\
\hline Persentase kegiatan & $85,56 \%$ & $85,28 \%$ \\
\hline Taraf keberhasilan & Sangat Baik & Sangat Baik \\
\hline
\end{tabular}

Berdasarkan hasil observasi kegiatan siswa, diketahui bahwa siswa telah melakukan kegiatan pembelajaran dengan sangat baik dengan taraf keberhasilan sebesar $85,28 \%$. Hal ini ditunjukkan dengan kesesuaian kegiatan siswa dengan langkah-langkah model pembelajaran learning cycle $7 E$, yaitu (1) siswa telah menjawab pertanyaan yang diajukan oleh guru berdasarkan pengetahuan yang didapat, (2) siswa telah memberikan pendapat mengenai pertanyaan yang diajukan guru dan demontrasi yang telah dilakukan, (3) siswa telah berdiskusi kelompok tentang masalah yang sedang amati, (4) siswa mengajukan pendapat mengenai penjelasan kelompok lain yang sedang menyajikan hasil diskusi kelompoknya, (5) siswa menggunakan konsep dan pengetahuan yang telah diperoleh untuk menyelesaiakan soal rutin, dan (6) siswa menggunakan konsep yang telah didapat kedalam situasi baru sebagai aplikasi konsep yang dipelajari baik dari suatu konsep ke konsep lain, bidang ilmu lain maupun kedalam kehidupan sehari-hari. Dengan demikian, proses pembelajaran yang dilalui partisipan yang diajar dengan menggunakan model learning cycle $7 E$ telah melalui setiap tahap model learning cycle $7 E$, sehingga peneliti dapat memastikan bahwa hasil kemampuan representasi matematis siswa yang diproleh merupakan akibat dari perlakuan.

Tabel 6: Data Observasi Kegiatan Siswa Kelas Kontrol

\begin{tabular}{lll}
\hline Pertemuan Ke- & Skor Pengamat I & Skor Pengamat II \\
\hline Pertemuan ke-1 & 64 & 68 \\
\hline Pertemuan ke-2 & 70 & 68 \\
\hline
\end{tabular}




\begin{tabular}{lll}
\hline Pertemuan ke-3 & 68 & 70 \\
\hline Skor rata-rata & 67,33 & 68,67 \\
\hline Persentase kegiatan & $68,01 \%$ & $69,36 \% \%$ \\
\hline Taraf keberhasilan & Baik & Baik \\
\hline
\end{tabular}

Berdasarkan hasil observasi kegiatan siswa, siswa tidak memberikan tanggapan terhadap pendapat siswa lainnya yang sedang mempresentasikan hasil pekerjaaannya. karena sebagian besar siswa terlihat bosan dan sibuk dengan kegiatannya sendiri. Hal ini didukung catatan pengamat pada lembar observasi, bahwa sebagian siswa terlihat mengantuk dan masih banyak yang belum menyelesaikan tugas mandirinya.

Subjek wawancara kemampuan representasi matematis adalah siswa yang memiliki selfconcept positif dan negatif dari masing-masing kelas. Subjek wawancara terdiri dari 2 siswa yang memiliki self-concept positif dan 2 siswa yang memiliki self-concept negatif.

Berdasarkan data yang telah diperoleh dari hasil wawancara dan posstest pada subjek E10 dan E28, dapat diketahui bahwa subjek E10 dan E28 telah memenuhi setiap indikator kemampuan representasi matematis cukup baik. Subjek E10 dan E28 telah memenuhi indikator representasi visual, dibuktikan oleh data hasil wawancara yang menyatakan bahwa subjek E10 dan E28 mampu menggambar hubungan dan kedudukan garis dengan benar. Namun, yang membedakan dari kedua subjek adalah subjek E10 mampu memberikan nama terhadap garis yang digambar meskipun pewawancara tidak menyebutkan nama dari masing-masing garis. Hasil wawancara ini, memperjelas data hasil posttest yang menggambarkan bahwa subjek E10 telah menggambar langkah-langkah membagi garis menjadi beberapa bagian secara lengkap. Sedangkan subjek E28 telah menggambar langkah-langkah membagi garis menjadi beberapa bagian lebih dari 50\%. Pada indikator representasi ekspresi matematik, subjek E10 dan E28 mampu membuat persamaan/model matematik dari representasi lain yang diberikan serta dapat menerapkannya dalam menyelesaikan masalah. Hal ini dibuktikan dengan cara subjek E10 dan E28 mampu membuat model perbadingan dan dapat menentukan panjang ruas garis. Subjek E10 mampu membuat model perbandingan sebanyak 3 dari 10 model perbandingan yang seharusnya dan mampu menentukan model perbandingan yang digunakan untuk menyelesaikan soal Nomor 4a, sedangkan subjek E28 mampu menyebutkan 2 model perbadingan, namun masih kebingungan dalam menentukan model perbandingan yang digunakan untuk menyelesaikan soal Nomor 4a. Selian itu subjek E10 dan E28 juga telah memenuhi indikator representasi verbal. Hal ini dibuktikan dengan cara subjek E10 dan E28 mampu memberikan penjelasan matematis tentang langkah-langkah membagi garis menjadi beberapa bagian, meskipun masih ada bahasa yang kurang baku dalam penjelasannya.

Data hasil wawancara menunjukkan bahwa subjek E20 dan E23 memenuhi indikator kemampuan representasi dengan baik. Subjek E20 telah memenuhi indikator kemampuan represensi visual dengan baik, dibuktikan dengan cara subjek E20 mampu menggambar hubungan dan kedudukan garis meskipun masih kurang tepat dalam menggambar garis, sinar garis dan pemberian nama pada masing-masing garis, sedangkan subjek E23 mampu menggambar namun hanya menunjukkan ketidakpahaman. Pada representasi ekspresi matematik subjek E20 masih kurang memenuhi, karena subjek hanya bisa membuat model perbandingan yang biasa digunakan dalam latihan rutin misalnya salah satu model perbandingan pada soal Nomor 4a yaitu "AE:AD = EG:DC". Namun subjek bisa menerapkan model perbandingan yang telah dibuat dalam menyelesaikan masalah. Subjek E23 mampu dalam membuat model perbandingan dari suatu gambar dan mampu menerapkannya dalam menyelesaikan masalah. Subjek E23 mampu menyebutkan 3 model perbandingan dari 10 model perbandingan yang seharusnya serta mampu menentukan model perbandingan yang digunakan untuk menyelesaikan soal Nomor 4a. Pada representasi verbal subjek E20 mampu memuat interpretasi dari representasi lain akan tetapi subjek E20 belum mampu menjelaskan prosedur matematis dari membagi garis menjadi beberapa bagian. Subjek E23 mampu memberikan interpretasi dari representasi lain namun tidak mampu 
memjelaskan suatu prosedur matematis seperti langkah-langkah membagi garis menjadi beberapa bagian.

Berdasarkan data yang telah diperoleh dari hasil wawancara subjek K3 dan K28, diketahui bahwa subjek K3 telah memenuhi indikator kemampuan representasi matematis cukup baik dan K28 telah memenuhi setiap indikator kemampuan representasi matematis dengan baik. Subjek K3 tidak memenuhi indikator representasi verbal karena subjek K3 tidak dapat memberikan interpretasi dari suatu representasi lain dan tidak mampu menjelaskan suatu prosedur matematis seperti membagi garis menjadi beberapa bagian. Namun, subjek K3 memenuhi indikator representasi visual dan ekspresi matematik dengan baik. Hal ini ditunjukkan dengan cara subjek K3 mampu menggambar hubungan dan kedudukan titik, garis, dan bidang dengan benar meskipun tidak memberikan nama hterhadap masing-masing garis. Selain representasi visual, subjek K3 juga mampu membuat model perbandingan dan dapat menerapkannya dalam menyelesaikan masalah, dibuktikan dengan kemampuan subjek K3 membuat 2 model perbandingan dan dapat menentukan model perbadingan yang digunakan untuk menyelesaikan soal nomor 4a. Subjek K28 telah memenuhi setiap indikator kemampuan representasi dengan baik. Subjek K28 mampu menggambar hubungan dan kedudukan titik, garis, dan bidang. dengan benar dan mempu memberikan nama pada masing-masing garis. Subjek K28 mampu membuat model perbandingan dan merapkannya dalam menyelesaikan masalah. Model perbandingan yang dapat dibuat oleh subjek K28 sebanyak 4 dari 10 model perbandingan yang seharusnya serta dapat menentukan model perbandingan yang digunakan untuk menyelesaikan soal Nomor 4a. Selain itu, subjek K28 juga dapat memberikan interpretasi dari suatu representasi lain dan dapat menjelaskan suatu prosedur matematis seperti langkah-langkah membagi garis menjadi beberapa bagian merkipus masih kurang sistematis.

Berdasarkan hasil data wawancara dan posttest yang dilakukan pada subjek K1 dan K27, diketahui bahwa subjek K1 dan K27 hanya memenuhi dua indikator kemampuan representasi matematis dengan cukup baik. Subjek K1 dan K27 mampu menggambar hubungan dan kedudukan titik, garis, dan bidang namun kurang tepat dalam merepresentasikan garisnya, sedangkan K27 hanya benar pada garis-garis sejajarnya. Pada indikator representasi ekspresi matematik, subjek K1 hanya mampu membuat 2 model perbandingan dan mampu menentukan salah satu model perbandingan yang digunakan untuk menyelesaikan soal Nomor 4a, sedangkan Subjek K27 tidak mampu membuat model perbandingan. Pada indikator representasi verbal subjek K1 dan K27 tidak dapat memberikan interprestasi dari representasi lain dan tidak mampu menjelaskan suatu prosedur matematis seperti langkah-langkah membagi garis menjadi beberapa bagian.

Ananlisis data kuantitatif dan kualitatif dilakukan dengan cara membandingkan data kuantitatif hasil penelitian tahap pertama dengan data kualitatif hasil penelitian tahap kedua. Pada tahap ini, data yang akan dibandingkan adalah data hasil posttest dan data hasil wawancara kemampuan representasi matematis kelas eksperimen (E) dan kelas kontrol (K). berdasarkan hasil analisis data kuantitatif dan kualitatif, diketahui bahwa penelitian kualitatif pada tahap kedua dapat menghasilkan data kualitatif yang membuktikan, melengkapi, dan memperluas data kuantitatif kemampuan representasi matematis. Adapun perbandingan data kuantitatif dan data kualitatif dapat dilihat pada Tabel 7 dan Tabel 8.

Tabel 7: Data Hasil Posttest dan Wawancara Siswa Dengan Self-Concept Positif

\begin{tabular}{|c|c|c|c|c|}
\hline Indikator Representasi & Data $P o$ & ttest & Data Wawancara & \\
\hline & $E$ & $\mathrm{~K}$ & $E$ & $\mathrm{~K}$ \\
\hline $\begin{array}{lr}\text { Visual: } & \\
\text { Membuat } & \text { gambar } \\
\text { geometri } & \text { untuk } \\
\text { memperjelas } & \text { masalah } \\
\text { dan memfasilitasi } & \\
\text { penyelesaian. } & \end{array}$ & $83,33 \%$ & $75 \%$ & $\begin{array}{lr}\text { Mampu } & \text { membuat } \\
\text { gambar } & \text { geometri } \\
\text { hubungan } & \text { dan } \\
\text { kedudukan } & \text { titik, garis, } \\
\text { dan bidang. } & \end{array}$ & $\begin{array}{l}\text { Mampu membuat } \\
\text { gambar geometri } \\
\text { hubungan dan } \\
\text { kedudukan titik, } \\
\text { garis, dan bidang. }\end{array}$ \\
\hline $\begin{array}{l}\text { Ekpresi matematik: } \\
\text { Membuat } \quad \text { persamaan }\end{array}$ & $79,17 \%$ & $75 \%$ & $\begin{array}{lr}\text { Mampu } & \begin{array}{r}\text { membuat } \\
\text { model }\end{array} \\
\text { perbandingan }\end{array}$ & $\begin{array}{l}\text { Mampu } \\
\text { model }\end{array}$ \\
\hline
\end{tabular}




\begin{tabular}{|c|c|c|c|c|}
\hline $\begin{array}{l}\text { atau model matematik } \\
\text { dari representasi lain } \\
\text { yang diberikan. }\end{array}$ & & & $\begin{array}{l}\text { dari representasi } \\
\text { gambar yang diberikan. }\end{array}$ & $\begin{array}{l}\text { perbandingan dari } \\
\text { representasi gambar } \\
\text { yang diberikan. }\end{array}$ \\
\hline $\begin{array}{l}\text { Ekpresi matematik: } \\
\text { Menyelesaikan masalah } \\
\text { dengan melibatkan } \\
\text { ekspresi matematik. }\end{array}$ & $79,17 \%$ & $70,83 \%$ & $\begin{array}{l}\text { Mampu menghitung } \\
\text { panjang ruas garis dari } \\
\text { segitiga. }\end{array}$ & $\begin{array}{l}\text { Mampu } \\
\text { menghitung } \\
\text { panjang ruas garis } \\
\text { dari segitiga. }\end{array}$ \\
\hline $\begin{array}{l}\text { Verbal: } \\
\text { Menulis langkah-langkah } \\
\text { penyelesaian masalah } \\
\text { matematik dengan kata- } \\
\text { kata. }\end{array}$ & $70,83 \%$ & $62,5 \%$ & $\begin{array}{l}\text { Mampu menjelaskan } \\
\text { langkah-langkah } \\
\text { membagi ruas garis } \\
\text { menjadi beberapa } \\
\text { bagian. }\end{array}$ & $\begin{array}{l}\text { Cukup mampu } \\
\text { menjelaskan } \\
\text { langkah-langkah } \\
\text { membagi ruas garis } \\
\text { menjadi beberapa } \\
\text { bagian. }\end{array}$ \\
\hline $\begin{array}{l}\text { Verbal: } \\
\text { Menulis interpretasi dari } \\
\text { suatu representasi }\end{array}$ & $83,33 \%$ & $79,17 \%$ & $\begin{array}{l}\text { Mampu menjelaskan } \\
\text { hubungan dan } \\
\text { kedudukan antara titik, } \\
\text { garis, dan bidang dari } \\
\text { representasi gambar } \\
\text { yang diberikan. }\end{array}$ & $\begin{array}{l}\text { Mampu } \\
\text { menjelaskan } \\
\text { hubungan dan } \\
\text { kedudukan antara } \\
\text { titik, garis, dan } \\
\text { bidang dari } \\
\text { representasi gambar } \\
\text { yang diberikan. } \\
\end{array}$ \\
\hline Rata-rata & $79,17 \%$ & 72 & $\begin{array}{l}\text { Memenuhi } 5 \text { indikator } \\
\text { dengan baik }\end{array}$ & $\begin{array}{lr}\text { Memenuhi } & 4 \\
\text { indikator } & \text { dengan } \\
\text { baik } & \\
\end{array}$ \\
\hline
\end{tabular}

Berdasarkan Tabel 7, dapat disimpulkan bahwa data kualitatif yang diperoleh adalah mendukung, melengkapi, membuktikan, dan memperkuat data kauntitatif. Hal ini dibuktikan dengan kekonsistenan antara data kuantitatif dan data kualitatif dari setiap indikator pada kemampuan representasi matematis dan rata-ratanya menunjukkan perbedaan. Analisis data kuantitatif yang dibuktikan adalah hasil uji kesamaan rata-rata dua pihak pada data posttest diporoleh nilai $\mathrm{Sig}=0,009<0,05$ yang artinya terdapat perbedaan kemampuan representasi matematis yang signifikan antara kelas eksperimen dan kelas kontrol pada siswa yang memiliki self-concept positif pada materi garis kelas VII SMP Negeril Dau Malang.

Tabel 7: Perbandingan Data Hasil Posttest dan Wawancara kelas Kontrol

\begin{tabular}{|c|c|c|c|c|}
\hline Indikator Representasi & Data $P$ & ttest & Data Wawancara & \\
\hline & $\mathrm{E}$ & $\mathrm{K}$ & $\mathrm{E}$ & $\mathrm{K}$ \\
\hline \begin{tabular}{lr} 
Visual: & \\
Membuat & gambar \\
geometri & untuk \\
memperjelas & masalah \\
dan & memfasilitasi \\
\multicolumn{2}{c}{ penyelesaian. }
\end{tabular} & $87,5 \%$ & $66,7 \%$ & $\begin{array}{lr}\text { Mampu } & \text { membuat } \\
\text { gambar } & \text { geometri } \\
\text { hubungan } & \text { dan } \\
\text { kedudukan } & \text { titik, } \\
\text { garis, dan bidang. }\end{array}$ & $\begin{array}{l}\text { Cukup mampu } \\
\text { membuat gambar } \\
\text { geometri hubungan } \\
\text { dan kedudukan } \\
\text { titik, garis, dan } \\
\text { bidang. }\end{array}$ \\
\hline $\begin{array}{l}\text { Ekpresi matematik: } \\
\text { Membuat persamaan } \\
\text { atau model matematik } \\
\text { dari representasi lain } \\
\text { yang diberikan. }\end{array}$ & $70,8 \%$ & $62,5 \%$ & $\begin{array}{lr}\text { Mampu } & \text { membuat } \\
\text { model } & \text { perbandingan } \\
\text { dari } & \text { representasi } \\
\text { gambar } & \text { yang } \\
\text { diberikan. } & \\
\end{array}$ & $\begin{array}{l}\text { Cukup mampu } \\
\text { membuat model } \\
\text { perbandingan dari } \\
\text { representasi gambar } \\
\text { yang diberikan. }\end{array}$ \\
\hline $\begin{array}{l}\text { Ekpresi matematik: } \\
\text { Menyelesaikan masalah } \\
\text { dengan melibatkan } \\
\text { ekspresi matematik. }\end{array}$ & $70,8 \%$ & $58,33 \%$ & $\begin{array}{l}\text { Mampu menghitung } \\
\text { panjang ruas garis } \\
\text { dari sebuah segitiga. }\end{array}$ & $\begin{array}{l}\text { Cukup mampu } \\
\text { menghitung } \\
\text { panjang ruas garis } \\
\text { dari } \quad \text { sebuah } \\
\text { segitiga. }\end{array}$ \\
\hline $\begin{array}{l}\text { Verbal: } \\
\text { Menulis langkah-langkah } \\
\text { penyelesaian masalah } \\
\text { matematik dengan kata- }\end{array}$ & $62,5 \%$ & $41,67 \%$ & 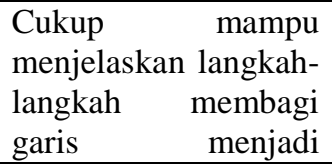 & $\begin{array}{l}\text { Kurang mampu } \\
\text { menjelaskan } \\
\text { langkah-langkah } \\
\text { membagi garis }\end{array}$ \\
\hline
\end{tabular}




\begin{tabular}{|c|c|c|c|c|}
\hline kata. & & & beberapa bagian. & $\begin{array}{l}\text { menjadi } \\
\text { bagian. }\end{array}$ \\
\hline $\begin{array}{l}\text { Verbal: } \\
\text { Menulis interpretasi dari } \\
\text { suatu representasi }\end{array}$ & $83,33 \%$ & $45,83 \%$ & $\begin{array}{l}\text { Mampu } \\
\text { menjelaskan } \\
\text { hubungan antara } \\
\text { titik, garis, dan } \\
\text { bidang. }\end{array}$ & $\begin{array}{l}\text { Kurang mampu } \\
\text { menjelaskan } \\
\text { hubungan antara } \\
\text { titik, garis, dan } \\
\text { bidang. }\end{array}$ \\
\hline Rata-rata & $74,99 \%$ & $55,01 \%$ & $\begin{array}{l}\begin{array}{l}\text { Memenuhi } \\
\text { indikator } \\
\text { baik }\end{array} \\
\text { dengan }\end{array}$ & $\begin{array}{l}\text { Memenuhi } \\
\text { indikator } \\
\text { baik }\end{array}$ \\
\hline
\end{tabular}

Berdasarkan Tabel 8, dapat disimpulkan bahwa data kualitatif yang diperoleh mendukung, melengkapi, membuktikan, dan memperkuat data kauntitatif. Hal ini dibuktikan dengan kekonsistenan antara data kuantitatif dan data kualitatif dari setiap indikator pada kemampuan representasi matematis. Analisis data kuantitatif yang dibuktikan adalah hasil uji kesamaan rata-rata dua pihak pada data posttest diporoleh nilai Sig $=0,005<0,05$ yang artinya terdapat perbedaan kemampuan representasi matematis yang signifikan antara kelas eksperimen dan kelas kontrol pada siswa yang memiliki self-concept negatif pada materi garis kelas VII SMP Negeri1 Dau Malang.

\section{PEMBAHASAN}

Berdasarkan hasil analisis data penelitian kuantitatif diperoleh jumlah siswa kelas eksperimen yang memiliki self-concept positif dan negatif masing-masing seanyak 16 dan 9. Pada siswa kelas kontrol yang memiliki self-concept positif dan negatif masing-masing sebanyak 16 dan 9. Hasil uji kesamaan rata-rata dua pihak pada siswa yang memiliki self-concept positif dan negatif diperoleh bahwa terdapat perbedaan kemampuan representasi matematis antara yang diajar dengan model learning cycle $7 E$ dan model konvenional berdasarkan jenis self-concept yang dimiliki siswa. Perbedaan ini diduga karena pengunaan model pembelajaran yang berbeda selama proses pembelajaran. Hal ini didukung oleh hasil penelitian Laelasari, Subroto, dan Duskri (2014:90) yang menyatakan bahwa mahasiswa yang diajar menggunakan model learning cycle $7 E$ dan mahasiswa yang diajar menggunakan model konvensional memberikan dampak yang berbeda terhadap kemampuan representasi matematis mahasiswa.

Model pembelajaran learning cycle $7 E$ cenderung menggunakan pola pembelajaran berfikir induktif. Pembelajaran terlebih dahulu mempelajari konsep-konsep yang kemudian diterapkan pada situasi baru. Penerapan model learning cycle $7 E$ terhadap siswa yang memiliki self-concept yang berbeda, maka akan memperoleh hasil yang berbeda pula. Hal ini didukung oleh penadapt Burns (dalam Rahman, 2012:20) yang menyatakan bahwa pandangan individu tentang dirinya yang dipengaruhi oleh cara individu menilai pandangan orang lain terhadap dirinya memberikan dampak dan kondisi yang berbeda, akibatnya setiap manusia memiliki kemampuan yang berbeda-beda. Hal ini dapat terjadi karena manusia memiliki kemampuan merefleksi dirinya sendiri yang disebut "selfconcept". Perbedaan self-concept yang dimiliki siswa berakibat pada kemampuan representasi matematis yang berbeda-beda. Sejalan dengan pendapat tersebut, Jatmiko (2017:94) dalam penelitiannya menyimpulkan bahwa model pembelajaran dan self-concept siswa sangat mempengaruhi dan menentukan keberhasilan siswa dalam memperoleh hasil belajar yang lebih baik.

Selain model pembelajaran yang memberikan pengaruh, self-concept yang dimiliki siswa juga berpengaruh terhadap kemampuan representasi matematis siswa. Hal ini disampaikan oleh Pamungkas (2013:53) dalam dengan judul "konstribusi self-concept matematis dan mathematics anxity terhadap hasil belajar mahasiswa". kesimpulan dari penelitian tersebut menyatakan bahwa Self-concept memberikan kontribusi sebesar $47,4 \%$ terhadap hasil belajar matematika. Sejalan dengan hasil penelitian yang dilakukan Pamungkas, Yarmawati (2014) dalam penelitiannya yang berjudul "pengaruh pembelajaran realistic matematics education terhadap konsep diri dan 
kemampuan representasi matematika siswa SMA Plus 7 Kota Bengkulu" menyimpulkan bahwa self-concept berpengaruh langsung positif terhadap kemampuan representasi matematika.

Berdasarkan uji kesamaan rata-rata satu pihak diperoleh hasil, bahwa kemampuan representasi matematis siswa yang diajar menggunakan model learning cycle $7 E$ lebih baik dari pada yang diajar menggunakan model konvensional baik siswa yang memiliki self-concept positif maupun negatif. Hasil analisis data tersebut menggambarkan bahwa model learning cycle $7 E$ memberikan efek kontribusi lebih baik terhadap kemampuan representasi matematis baik siswa yang memiliki self-concept positif maupun negatif. Hal ini diduga karena model Learning cycle $7 E$ dapat memberikan kesempatan kepada siswa untuk memperoleh pengalaman secara langsung dengan lingkungannya, sehingga siswa dapat mengetahui kegunaan konsep yang dipelajari dan siswa dapat membangun konsepnya sendiri. Dugaan tersebut didasarkan pada fase-fase belajar dalam learning cycle secara umum yang disampaikan oleh Carin (dalam Jatmiko, 2017:85) bahwa fase-fase belajar dalam learning cycle, yaitu (1) siswa dapat memperoleh pengalaman langsung dengan lingkungan, (2) siswa dapat membangun konsep pengetahuannya sendiri, dan (3) siswa ditekankan untuk dapat menerapkan konsep yang dipahami pada situasi baru. Dugaan tersebut juga didukung oleh hasil observasi yang menggambarkan bahwa proses pembelajaran dengan model learning cycle $7 E$ berlangsung dengan baik, dibuktikan melalui kegiatan guru dan siswa yang telah menyelesaikan setiap fase pembelajaran dalam model learning cycle $7 E$.

Proses pembelajaran pada model learning cycle $7 E$ lebih menekankan pada pengalaman siswa dalam memahami konsep, sehingga siswa dapat mengetahui manfaaat mempelajari materi garis. Proses pembelajaran learning cycle $7 E$ juga menekankan keaktifan dalam kelompok, sehingga siswa yang memilki self-concept positif dan negatif dapat bekerjasama dan mengembangkan potensi diri masing-masing. Proses pembelajaran pada model konvensional lebih berfokus pada kegiatan guru. Siswa yang memiliki self-concept negatif akan cenderung meniru apa yang dikerjakan oleh orang lain, sehingga jika mengalami kesulitan dalam menyelesaikan tugas mandiri akan menunggu hasil pekerjaan temannya. Pernyataan tersebut didukung dengan teori yang disampaikan oleh Bandaru (dalam Jatmiko, 2017:97) bahwa seseorang yang memiliki tingkat keberhasilan rendah ditandai dengan aspirasi dan komitmen yang rendah sehingga ia akan menghindar dari tugas-tugas yang menyulitkan. Karena sikap tersebut, model konvensional untuk siswa yang memiliki self-concept negatif tidak dapat memberikan pengaruh yang lebih baik.

Pada penelitian kualitatif, kemampuan representasi yang dideskripsikan berdasarkan pada jenis self-concept yang dimiliki, yaitu self-concept positif dan negatif. Analisis data kualitatif di lakukan pada 4 siswa kelas VII D sebagai kelas eksperimen dan 4 siswa kelas VII E seagai kelas kontrol. Masing-masing kelas akan diambil 2 siswa dengan self-concept positif dan 2 siswa dengan self-concept negatif. Dalam wawancara, peneliti memberikan pertanyann yang berkaitan dengan hasil posstest yang diperoleh siswa sesuai dengan indikator kemampuan representasi matematis.

Berdasarkan hasil analisis wawancara kelas eksperimen, diperoleh bahwa. Subjek E28 yang memiliki self-concept positif telah memenuhi setiap indikator kemampuan representasi matematis dengan baik, yaitu representasi visual dengan indikator membuat gambar geometri untuk memperjelas masalah dan memfasilitasi penyelesaian, representasi ekspresi matematik dengan indikator membuat persamaan atau model matematik dari representasi lain yang diberikan dan menyelesaikan masalah dengan melibatkan ekspresi matematik, dan representasi verbal dengan indikator menjelaskan langkah-langkah penyelesaian masalah matematik dan menulis interpretasi dari suatu representasi. Efek ini terjadi disebabkan oleh karena siswa memandang dirinya sebagai individu yang memiliki kemampuan secara fisik, psikologis, serta pengetahuan akademis yang baik. Subjek 23 tidak dapat memenuhi indikator representasi verbal yaitu tidak mampu menjelaskan langkah-langkah penyelesaian masalah matematik. Hal ini terjadi karena rasa percaya diri yang rendah, sehingga siswa masih memandang dirinya sebagai individu yang kurang mampu secara kademis. Ungkapan tersebut didukung oleh pendapat Suna (dalam Jatmiko, 2017:95) bahwa orang yang menilai dirinya secara positif akan menjalani kehidupannya dengan rasa percaya diri dan 
penuh keyakinan. Penjelasan ini menggambarkan bahwa, percaya diri mempengaruhi tingkat keberhasilan.

Berdasarkan hasil analisis wawancara kelas kontrol, diperoleh bahwa subjek K28 telah memenuhi setiap indikator kemampuan representasi matematis dengan baik, yaitu representasi visual dengan indikator membuat gambar geometri untuk memperjelas masalah dan memfasilitasi penyelesaian, representasi ekspresi matematik dengan indikator membuat persamaan atau model matematik dari representasi lain yang diberikan dan menyelesaikan masalah dengan melibatkan ekspresi matematik, dan representasi verbal dengan indikator menjelaskan langkah-langkah penyelesaian masalah matematik dan menulis interpretasi dari suatu representasi. Namun masih kurang pada indikator menjelaskan langkah-langkah penyelesaian masalah matematik. sedangkan subjek K1 dapat memenuhi 3 indikator kemampuan representasi, yaitu indikator dari representasi visual dan representasi ekspresi matematik. Pada indikator representasi visual subjek K1 dapat memenuhi indikator membuat gambar geometri untuk memperjelas masalah dan memfasilitasi penyelesaian. Pada indikator representasi ekspresi matematik subjek K1 dapat memenuhi indiakator membuat model perbandingan dari representasi lain yang diberikan dan mampu menerapkannya dalam menyelesaikan masalah. Perbedaan hasil yang diperoleh terjadi karena penerapan model yang tidak sesuai dengan krakteristik yang dimiliki siswa. Model pembelajaran yang digunakan tidak dapat mengakomudir setiap krakteristik yang dimiliki siswa, sehingga pembelajaran menjadi tidak efektif. Ketidak sesuaian model pembelajaran dengan karakteristik siswa berakibat pada terhambatnya perkembangan berfikir siswa.

Keterbatasan penelitian ini adalah pengontrolan terhadap variabel bebas diluar variabel yang diteliti. Pelaksanaan penelitian dilaksanakan di lembaga pendidikan sehingga sampel penelitian hanya dapat diambil dari kelompok kelas yang telah ada dan dalam waktu yang singkat, yaitu 3 pertemuan pada masing-masing kelas. Maka hasil yang diperoleh kemungkinan bukan murni dari perlakuan. Pengambilan sampel dilakukan melalui pertimangan tertentu karena keadaan kelas telah disusun berdasarkan kemampuan siswa. Penelitian ini dilakukan pada sampel yang relatif kecil, yaitu 50 siswa yang terbagi menjadi empat kelompok. Melihat kondisi seperti ini, maka penggeneralisasian hasil penelitian hanya berlaku pada sekolah tempat penelitian, yaitu SMP Negeri 1 Dau Malang.

\section{SIMPULAN DAN SARAN}

Berdasarkan hasil penelitian yang dilaksanakan mengenai kemampuan representasi matematis siswa kelas VII SMP Negeri 1 Dau Malang pada materi garis dengan menggunakan model pembelajaran learning cycle $7 E$ berdasarkan self-concept siswa, diperoleh simpulan sebagai berikut.

1) Hasil analisis data kuantitatif dengan uji kesamaan rata-rata dua pihak menggunakan software SPSS 23, pada siswa yang memiliki self-concept positif diperoleh kesimpulan bahwa terdapat perbedaan kemampuan representasi matematis antara yang diajar menggunakan model learning cycle $7 E \mathrm{dn}$ model konvensional untuk siswa yang memiliki self-concept positif pada materi garis kelas VII SMP Negeri 1 Dau Malang.

2) Hasil analisis data kuantitatif dengan uji kesamaan rata-rata dua pihak menggunakan software SPSS 23, pada siswa yang memiliki self-concept positif diperoleh kesimpulan bahwa terdapat perbedaan kemampuan representasi matematis antara yang diajar menggunakan model learning cycle $7 E$ dn model konvensional untuk siswa yang memiliki self-concept negatuf pada materi garis kelas VII SMP Negeri 1 Dau Malang.

3) Kemampuan representasi matematis siswa yang memiliki self-concept positif dan diajar menggunakan model learning cycle $7 E$ termasuk dalam kategori baik. Kemampuan representasi matematis siswa yang memiliki self-concept negatif dan diajar menggunakan model learning cycle $7 E$ termasuk dalam kategori baik. Kemampuan representasi matematis siswa yang memiliki self-concept positif dan diajar menggunakan model konvensional termasuk dalam kategori cukup baik. Kemampuan representasi matematis siswa yang memiliki self-concept negatif dan diajar menggunakan model learning cycle $7 E$ termasuk dalam kategori kurang baik. 
4) Hasil analisis data kuantitatif dan kualitatif diperoleh informasi bahwa terdapat kemampuan representasi matematis antara kelas eksperimen dan kelas kontrol baik untuk siswa yang memilki concept positif maupun negatif. Perbedaan lebih spesifik digambarkan bahwa kemampuan representasi matematis siswa yang memiliki concept positif maupun negatif lebih baik diajar dengan model learning cycle $7 E$ dari pada model konvensional.

Dari hasil penelitian ini diharapkan dapat memberikan sumbangan ide-ide dalam upaya meningkatkan kualitas pembelajaran matematika, khususnya dalam melatih kemampuan representasi matematis siswa. Oleh karena itu, diberikan saran sebagai berikut.

1) Bagi Guru

Berdasarkan hasil penelitian secara kuantitatif maupun kualitatif bahwa siswa yang diajar menggunakan model learning cycle $7 E$ memiliki kemampuan representasi matematis yang lebih baik dari pada siswa yang ajar menggunakan model konvensional baik untuk siswa yang memiliki self-concept positif maupun negatif. Oleh karena itu model learning cycle $7 E$ dapat digunakan sebagai alternatif model pembelajaran agar dapat melatih kemampuan representasi matematis siswa. Model pembelajaran learning cycle $7 E$ membutuhkan kreativitas guru dalam mendesain pembelajaran sehingga dapat melalui semua fase, untuk itu bagi guru yang hendak menggunakan model pembelajaran learning cycle $7 E$ dalam pembelajaran di kelas diharapkan dapat menguasai materi dan langkah pembelajaran terlebih dahulu, sehingga setiap langkah pada model learning cycle $7 E$ tidak ada yang terlewati baik karena kendala waktu atau kondisi siswa.

2) Bagi Peserta Didik

Dalam setiap pembelajaran dengan model learning cycle $7 E$ siswa sebaiknya dituntut untuk lebih mempersiapkan diri dan materi agar dapat menciptakan suasana belajar yang menyenangkan serta belajar percaya diri dalam mengungkapkan ide-ide selama proses pembelajaran, sehingga dalam belajar matematika peserta didik menjadi berani dan percaya diri dalam beragumen atau mengemukakan pendapatnya.

3) Bagi Peneliti Selanjutnya

Bagi peneliti selanjutnya yang akan mengadakan penelitian tentang model pembelajaran model learning cycle $7 E$ terhadap kemampuan representasi matematis jika ditinjau dari segi afektif siswa, disarankan melakukan penelitian pada kemampuan matematis lainnya, seperti kemampuan pemahaman konsep, kemampuan pemecahan masalah, dan lain sebagainya.

\section{DAFTAR RUJUKAN}

Creswell, J. (2015). Educational Research. Planing, Conducting, and Evaluating Quantitative and Qualitative. Terjemahan oleh Helly Prajitno Soetjipto dan Sri Mulyani Soetjipto. Yogyakarta: Pustaka Pelajar.

Fitri, N., Munzir, S., \& Duskri. (2017). Meningkatkan Kemampuan Representasi Matematis melalui Penerapan Model Problem Based Learning. Didaktik Matematika, 4(1), 59-67.

Jatmiko, A. (2017). Pengaruh Model Pembelajaran dan Konsep Diri terhadap Hasil Belajar IPA. Biosfer, 8(2), 84-101.

Laelasari, Subroto, T., \& Ikhsan, N. (2014). Penerapan Model Pembelajaran Learning Cycle 7E dalam Kemampuan Representasi Matematis Mahasiswa. Euclid, 1(2), 82-92.

NCTM. (2000). Principle and Standards for School Mathematics. Reston VA: National Council of Teacher.

Pamungkas, A. S. (2014). Konstribuasi Self-Concept Mathematics dan Mathematics Anxiety terhadap Hasil Belajar Matematika. http://download.portalgaruda.org/article.php.

Peraturan Menteri Pendidikan Nasional Republik Indonesia Nomor 22 Tahun 2006 tentang Tujuan Pembelajaran Matematika. Jakarta: Depdiknas.

Rahman, R. (2012). Hubungan antara Self-Concept terhadap Matematika dengan Kemampuan berpikir Kreatif Matematik Siswa. Infinity, 1(1), 19-30.

Sugiyono. (2016). Metode Penelitian Kuantitatif Kualitatif dan Kombinasi (Mixed Methods). Bandung: Alfabeta.

Suryowati, E. (2015). Kesalahan Siswa Sekolah Dasar dalam Merepresentasikan Pecahan pada Garis Bilangan. Aksioma, 4(1), 38-52. 
Yarmawati. (2014). Pengaruh Pembelajaran Realistic MathematicEducation terhadap Konsep Diri dan Kemampuan Representasi Matematika Siswa SMA Plus 7 Bengkulu. Tesis tidak diterbitkan. Bengkulu: Program Pasca Sarjana Universitas Bengkulu. 